\title{
Effectiveness of isoniazid preventative therapy in reducing incidence of active tuberculosis among people living with HIV/ AIDS in public health facilities of Addis Ababa, Ethiopia: a historical cohort study
}

Mahlet Semu', Teferi Gedif Fenta ${ }^{2 *}$, Girmay Medhin ${ }^{3}$ and Dawit Assefa ${ }^{4}$

\begin{abstract}
Background: Human Immunodeficiency Virus (HIV) pandemic has exacerbated tuberculosis disease especially in Sub-Saharan African countries. The World Health Organization (WHO) and Joint United Nations Program on HIV/ AIDS (UNAIDS) have recommended Isoniazid Preventive Therapy (IPT) for HIV infected patients to reduce the burden of tuberculosis (TB). Ethiopia has been implementing IPT since 2007. However, effectiveness of IPT in averting occurrence of active tuberculosis among HIV infected patients has not been assessed.
\end{abstract}

Methods: Retrospective cohort study was employed using secondary data from public health institutions of Addis Ababa. Descriptive statistics and Generalized Linear Model based on Poisson regression was used for data analysis.

Results: From 2524 HIV infected patients who were followed for 4106 Person-Years, a total of 277 incident Tuberculosis (TB) cases occurred. TB Incidence Rate was 0.21/100 Person-Year, 0.86/100 Person-Year \& 7.18/100 Person-Year among IPT completed, in-completed and non-exposed patients, respectively. The adjusted Incidence Rate Ratio (aIRR) among IPT completed vs. non-exposed patients was 0.037 (95\% Cl, 0.016-0.072). Gender, residence area, employment status, baseline WHO stage of the disease (AIDS) and level of CD4 counts were identified as risk factors for TB incidence. The alRR among patients who took Highly Active Anti- Retroviral Therapy (HAART) with IPT compared to those who took HAART alone was 0.063 (95\% Cl 0.035-0.104). IPT significantly reduced occurrence of active TB for 3 years.

Conclusions: IPT significantly reduced tuberculosis incidence by $96.3 \%$ compared to IPT non-exposed patients. Moreover concomitant use of HAART with IPT has shown a significant reduction in tuberculosis incidence by 93.7\% than the use of HAART alone. Since IPT significantly protected occurrence of active TB for 3 years, its implementation should be further strengthened in the country.

Keywords: IPT, Incidence of active TB, TB/HIV co-infection, Ethiopia

\footnotetext{
* Correspondence: tgedif@gmail.com

${ }^{2}$ Social and Administrative Pharmacy Working Group, Department of

Pharmaceutics and Social Pharmacy, College of Health Sciences, Addis Ababa

University, P.O. Box 1176, Addis Ababa, Ethiopia

Full list of author information is available at the end of the article
} 


\section{Background}

Tuberculosis (TB) and Human Immunodeficiency virus/ Acquired Immunodeficiency Syndrome (HIV/AIDS) are major public health threat [1-3]. Among HIV infected patients, $\mathrm{TB}$ is the most frequent life threatening

Table 1 Socio-demographic characteristics of patients at enrollment for chronic HIV care in public health facilities of Addis Ababa, during 2007-June 2012

\begin{tabular}{|c|c|c|c|c|}
\hline $\begin{array}{l}\text { Socio-demographic } \\
\text { profile at enrollment for } \\
\text { HIV care }(N=2524)\end{array}$ & $\begin{array}{l}\text { IPT Exposed } \\
N(\%)\end{array}$ & $\begin{array}{l}\text { IPT Non- } \\
\text { exposed } \\
N(\%)\end{array}$ & $\begin{array}{l}\text { Total } \\
N(\%)\end{array}$ & $\begin{array}{l}\text { Chi-square } \\
P \text { value }\end{array}$ \\
\hline \multicolumn{5}{|l|}{ Sex } \\
\hline Male & 473(37.4) & $469(37.2)$ & $942(37.3)$ & \multirow[t]{2}{*}{0.918} \\
\hline Female & $791(62.6)$ & $791(62.8)$ & $1582(62.7)$ & \\
\hline \multicolumn{5}{|c|}{ Age in years $($ mean $=34.9, S D=9.1)$} \\
\hline$<30$ & $421(33.3)$ & $557(44.2)$ & $978(38.7)$ & \multirow[t]{4}{*}{0.150} \\
\hline $30-39$ & 408(32.3) & $412(32.7)$ & $820(32.5)$ & \\
\hline $40-49$ & $283(22.4)$ & 247(19.6) & $530(21)$ & \\
\hline$>50$ & $152(12)$ & $44(3.5)$ & 196(7.8) & \\
\hline \multicolumn{5}{|l|}{ Marital status } \\
\hline Single & $318(25.2)$ & 288(22.9) & $606(24)$ & \multirow[t]{5}{*}{0.000} \\
\hline Married & $584(46.2)$ & $551(43.7)$ & $1135(45)$ & \\
\hline Widowed & 189(15) & 195(15.5) & $384(15.2)$ & \\
\hline Separated & $157(12.4)$ & $165(13.1)$ & $322(12.8)$ & \\
\hline Divorced & $16(1.3)$ & $61(4.8)$ & $77(3.1)$ & \\
\hline \multicolumn{5}{|l|}{ Level of Education } \\
\hline No formal education & 248(19.6) & $276(21.9)$ & $524(20.8)$ & \multirow[t]{4}{*}{0.004} \\
\hline Primary completed & $507(40.1)$ & $447(35.5)$ & 954(37.8) & \\
\hline Secondary completed & $473(37.4)$ & $473(37.5)$ & $946(37.5)$ & \\
\hline Tertiary completed & $36(2.8)$ & $64(5.1)$ & $100(4)$ & \\
\hline \multicolumn{5}{|l|}{ Religion } \\
\hline Orthodox & $979(77.5)$ & $1023(81.2)$ & 2002(79.3) & \multirow[t]{4}{*}{0.197} \\
\hline Muslim & $98(7.8)$ & $177(14)$ & 275(10.9) & \\
\hline Protestant & $132(10.4)$ & $54(4.3)$ & $236(9.4)$ & \\
\hline Others $^{a}$ & $5(0.4)$ & $6(0.5)$ & $11(0.4)$ & \\
\hline \multicolumn{5}{|l|}{ Employment status } \\
\hline Non-employed & $650(51.4)$ & 483(38.3) & 1133(44.9) & \multirow[t]{5}{*}{0.000} \\
\hline Self-employed & $218(17.2)$ & 247(19.6) & $465(18.4)$ & \\
\hline $\begin{array}{l}\text { Government } \\
\text { employed }\end{array}$ & $205(16.2)$ & 248(19.7) & $453(17.95)$ & \\
\hline Private & $183(14.5)$ & $270(21.4)$ & $453(17.95)$ & \\
\hline Student & $8(0.63)$ & $12(0.95)$ & $20(0.8)$ & \\
\hline \multicolumn{5}{|l|}{ Residence place } \\
\hline Addis Ababa & $1230(97.3)$ & 1252(99.4) & 2482(98.3) & \multirow[t]{2}{*}{0.322} \\
\hline Out of Addis Ababa & $34(2.7)$ & $8(0.6)$ & $42(1.7)$ & \\
\hline $\begin{array}{l}\text { Average no. of personnel } \\
\text { per family }\end{array}$ & 3.15 & 3.45 & 3.3 & 0.092 \\
\hline $\begin{array}{l}\text { Average no. of rooms } \\
\text { per family }\end{array}$ & 1.35 & 1.65 & 1.5 & 0.593 \\
\hline
\end{tabular}

${ }^{\mathrm{a} C a t h o l i c ~ a n d ~ J o b a ~}$ opportunistic disease, even in those receiving Highly Active Antiretroviral Therapy (HAART) and it has been shown to be a leading cause of death $[2,4,5]$. HIV infection is also the strongest risk factor for TB disease [3]. In 2011, globally there were 34 million HIV infected patients and at least one-third of these had latent TB \& 1.1 million of them developed new TB infection, of these around $79 \%$ of patients were from Sub-Saharan African countries, indicating that HIV is fueling the TB epidemics in the region [5]. In Ethiopia like many of the developing countries, TB has created major burden to the health care system due to its linkage with HIV/AIDS

Table 2 Baseline clinical information of HIV positive patients in public health facilities of Addis Ababa, during 2007-June 2012

\begin{tabular}{|c|c|c|c|c|}
\hline $\begin{array}{l}\text { Baseline Clinical } \\
\text { status }(N=2524)\end{array}$ & $\begin{array}{l}\text { IPT Exposed } \\
N(\%)\end{array}$ & $\begin{array}{l}\text { IPT Non- } \\
\text { exposed } \\
N(\%)\end{array}$ & $\begin{array}{l}\text { Total } \\
N(\%)\end{array}$ & $\begin{array}{l}\text { Chi-square } \\
P \text { value }\end{array}$ \\
\hline \multicolumn{5}{|c|}{ Initial WHO stage of HIV/AIDS } \\
\hline Stage 1 & $357(28.2)$ & 215(17.1) & $572(22.7)$ & 0.000 \\
\hline Stage 2 & 487(38.5) & $346(27.5)$ & $833(33)$ & \\
\hline Stage 3 & $392(31)$ & $580(46)$ & $972(38.5)$ & \\
\hline Stage 4 & $28(2.3)$ & 119(9.4) & $147(5.8)$ & \\
\hline \multicolumn{5}{|c|}{ Baseline $C_{4}$ cells count $/ \mu \mathrm{l}($ mean $=230, \mathrm{SD}=176.9)$} \\
\hline$\leq 200$ & $570(45.1)$ & $807(64)$ & $1377(54.6)$ & 0.000 \\
\hline$>200$ & 694(54.9) & $453(36)$ & $1147(45.4)$ & \\
\hline
\end{tabular}

Initial body weight in $\mathrm{Kg}($ mean $=53.8, \mathrm{SD}=9.7)$

$\begin{array}{lllll}<50 & 304(24.1) & 554(43.8) & 858(34) & 0.009 \\ 50-59 & 628(49.7) & 418(33.1) & 1046(41.4) & \\ 60-69 & 208(16.5) & 214(17) & 422(16.7) & \\ >69 & 124(9.8) & 74(5.9) & 198(7.8) & \end{array}$

TB screened ${ }^{\mathrm{a}}$

$\begin{array}{lllll}\text { Positive } & 0 & 40(3.2) & 40(1.6) & \\ \text { Negative } & 1264(100) & 1220(96.8) & 2484(98.4) & \\ \text { On CPT } & & & & \\ \text { Yes } & 1259(99.6) & 1205(95.6) & 2464(97.6) & 0.000 \\ \text { No } & 5(0.4) & 55(4.4) & 60(2.4) & \end{array}$

Ols diagnosed

\begin{tabular}{|c|c|c|c|}
\hline None & 1082(85.6) & 907(71.9) & 1989(78.8) \\
\hline Bacterial infections & $11(0.87)$ & 164(13) & $175(6.9)$ \\
\hline Viral infections & $25(0.08)$ & $88(6.9)$ & $113(4.5)$ \\
\hline Fungal infections & $38(3)$ & $129(10.2)$ & $167(6.6)$ \\
\hline $\begin{array}{l}\text { Viral \& bacterial } \\
\text { infections }\end{array}$ & $20(1.6)$ & 13(1.03) & $33(1.3)$ \\
\hline $\begin{array}{l}\text { Bacterial \& fungal } \\
\text { infections }\end{array}$ & $11(0.87)$ & $8(0.63)$ & $19(0.8)$ \\
\hline $\begin{array}{l}\text { Fungal \& viral } \\
\text { infections }\end{array}$ & $8(0.6)$ & $12(0.95)$ & $20(0.8)$ \\
\hline
\end{tabular}

${ }^{\mathrm{a}} \mathrm{A}$ patient is TB positive, if he/she has at least two of these signs/symptoms: Weight loss greater than or equal to $5 \%$ of the initial weight, coughing for 2 weeks, night sweat, night-mar, Loss of appetite 
epidemics [6]. In 2010, TB incidence in HIV-positive patients was $48(27-76)$ per 100,000 population and the prevalence of TB including among HIV positives was 572(265-947) per 100,000 population [7].

Since 1998, WHO and the Joint United Nations Program on HIV/AIDS (UNAIDS) have recommended Isoniazid Preventive Therapy (IPT) as one of the key interventions in the comprehensive HIV/AIDS care strategy to reduce the burden of TB among HIV infected patients [8]. According to WHO [2], IPT given to HIV infected patients

Table 3 Clinical information of patients who were unheard follow upinpublic health facilities of Addis Ababa, during 2007-June 2012

\begin{tabular}{|c|c|c|c|c|}
\hline $\begin{array}{l}\text { Clinical information } \\
\text { when ART initiated } \\
(N=2046)\end{array}$ & $\begin{array}{l}\text { IPT exposed } \\
N(\%)\end{array}$ & $\begin{array}{l}\text { IPT Non- } \\
\text { exposed } \\
N(\%)\end{array}$ & $N(\%)$ & $\begin{array}{l}\text { Chi-square } \\
P \text { value }\end{array}$ \\
\hline \multicolumn{5}{|c|}{ WHO stage of HIV/AIDS } \\
\hline Stage 1 & 151(16.02) & $138(12.5)$ & $289(14.1)$ & \multirow[t]{4}{*}{0.000} \\
\hline Stage 2 & $367(39)$ & 294(26.6) & $661(32.3)$ & \\
\hline Stage 3 & $394(41.8)$ & $551(49.9)$ & $945(46.2)$ & \\
\hline Stage 4 & $30(3.18)$ & $121(11.0)$ & $151(7.4)$ & \\
\hline \multicolumn{5}{|c|}{$\mathrm{CD}_{4}$ cells count $/ \mu \mathrm{l}($ mean $=151.2, \mathrm{SD}=84.9)$} \\
\hline$\leq 200$ & $537(37.9)$ & 1020(92.4) & 1557(76.1) & \multirow[t]{2}{*}{0.000} \\
\hline$>200$ & $263(27.9)$ & $226(20.5)$ & 489(23.9) & \\
\hline \multicolumn{5}{|c|}{ Weight in $\mathrm{Kg}$ (mean $=53.2, \mathrm{SD}=9.5)$} \\
\hline$<50$ & $241(25.6)$ & $506(45.8)$ & $747(36.5)$ & \multirow[t]{4}{*}{0.011} \\
\hline $50-59$ & $479(44.2)$ & $366(33.1)$ & $845(41.3)$ & \\
\hline $60-69$ & $164(17.4)$ & 164(14.9) & $328(16.0)$ & \\
\hline$>69$ & $58(6.2)$ & $68(6.2)$ & $126(6.2)$ & \\
\hline \multicolumn{5}{|l|}{ TB screened } \\
\hline Yes & $942(100)$ & 1100(99.6) & 2042(99.8) & \multirow[t]{2}{*}{0.64} \\
\hline No & 0 & $4(0.4)$ & $4(0.2)$ & \\
\hline \multicolumn{5}{|l|}{ CPT adherence } \\
\hline Good & $791(84)$ & 1096(99.3) & 2032(99.6) & \multirow[t]{3}{*}{0.046} \\
\hline Fair & $3(.32)$ & $6(0.5)$ & $9(0.3)$ & \\
\hline Poor & $3(.32)$ & $2(0.2)$ & $5(0.2)$ & \\
\hline \multicolumn{5}{|l|}{ ART adherence } \\
\hline Good & $937(99.5)$ & 1100(99.6) & 2037(99.6) & \multirow[t]{3}{*}{0.124} \\
\hline Fair & $5(0.53)$ & $2(0.2)$ & $7(0.3)$ & \\
\hline Poor & 0 & $2(0.2)$ & $2(0.1)$ & \\
\hline \multicolumn{5}{|l|}{ Ols after ART initiated } \\
\hline None & $937(99.5)$ & 1052(95.3) & 1989(97.21) & \multirow[t]{6}{*}{0.000} \\
\hline Fungal & $3(.32)$ & $20(1.8)$ & 23(1.12) & \\
\hline Viral & 0 & $12(1.0)$ & $12(0.5)$ & \\
\hline Bacterial & 0 & $12(1.0)$ & $14(0.7)$ & \\
\hline Bacterial \& fungal & 0 & $4(0.4)$ & $4(0.2)$ & \\
\hline Others $^{\mathrm{a}}$ & 0 & $4(0.4)$ & $4(0.2)$ & \\
\hline
\end{tabular}

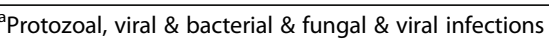

without TB disease reduces the risk of developing TB by $33-67 \%$ for up to 48 months. Regarding the concomitant use of HAART with IPT, a meta-analysis led by WHO found out that HAART reduces the individual risk of TB disease by $65 \%$, irrespective of the CD4 cell count but recent evidence has shown that the combined use of IPT and HAART among HIV infected patients significantly reduces the incidence of TB by up to $97 \%$ [9].

In Ethiopia, IPT provision for HIV infected patients is recommended by the national TB/HIV Collaborative Activities guideline and its implementation has been started since 2007[10]. However, the effectiveness of IPT in reducing the burden of active TB among HIV infected patients relative to those who did not take or discontinued has not been assessed yet. Moreover the clinical and programmatic factors affecting the treatment outcome among those who took have not been clearly identified. Therefore, this study assessed the effectiveness of the provision of IPT for HIV infected patients in averting occurrence of TB in the Ethiopian context.

\section{Methods}

A multi-centered retrospective cohort study design was employed using secondary data from 14 public health facilities giving ART service in Addis Ababa. From seven facilities which were giving IPT service between 2007 and January 2010, all adult HIV positive patients (1264) who were either on HAART or Pre-ART and exposed to IPT in the study period and who were followed for at

Table 4 Profile of IPT exposed patients inpublic health facilities of Addis Ababa, during 2007-June 2012

\begin{tabular}{lll}
\hline Profile $(N=1264)$ & $N(\%)$ & $\begin{array}{l}\text { Chi-square } \\
\text { P-value }\end{array}$ \\
\hline Male & $473(37.4 \%)$ & \\
Female & $791(62.6 \%)$ & \\
TB screened \& tested negative & $1264(100 \%)$ & \\
Currently on HAART & $942(74.5 \%)$ & \\
Pre-ART & $322(25.5 \%)$ & \\
HAART initiated before IPT & $578(61.3 \%)$ & \\
HAART initiated after IPT & $364(38.7 \%)$ & \\
IPT completed & $975(77.1 \%)$ & \\
IPT discontinued & $289(22.9 \%)$ & \\
On HAART + IPT completed & $738(78.3 \%)$ \\
Pre-ART + IPT completed & $237(73.6 \%)$ & \\
On HAART + IPT in-completed & $204(21.7 \%)$ & \\
Pre-ART + IPT in-completed & $85(26.4 \%)$ & \\
Male IPT completed & $359(75.9 \%)$ & \\
Female IPT completed & $616(77.8 \%)$ & \\
Took B6 together with INH & $581(46 \%)$ & \\
No IPT side effects & $1254(99.2 \%)$ & \\
\hline
\end{tabular}


Table 5 Incidence rate, univariate and multivariate analysis among IPT completed, in-completed and non- exposed patients in public health facilities of Addis Ababa, during 2007-June 2012

\begin{tabular}{|c|c|c|c|c|}
\hline Patient profile & Event/P/Y & IR/100P-Y & $\begin{array}{l}\text { Crude IRR } \\
(95 \% \mathrm{Cl})\end{array}$ & $\begin{array}{l}\text { Adjusted } \\
\text { IRR(95\% Cl) }\end{array}$ \\
\hline Over all & 277/4106 & 6.7 & & \\
\hline IPT completed & $7 / 33.3$ & 0.21 & $0.03(0.01-0.06)$ & $0.04(0.05-0.07)$ \\
\hline $\begin{array}{l}\text { IPT in- } \\
\text { completed }\end{array}$ & $8 / 7.8$ & 0.86 & $0.84(0.36-1.33)$ & $0.89(0.49-1.76)$ \\
\hline IPT non-exposed & $262 / 36.49$ & 7.18 & 1 & 1 \\
\hline \multicolumn{5}{|l|}{ Sex } \\
\hline Male & 138/2822.1 & 4.89 & $1.80(1.42-2.28)$ & $1.59(1.20-2.12)$ \\
\hline Female & 139/5129.2 & 2.71 & 1 & 1 \\
\hline \multicolumn{5}{|l|}{ Age group in year } \\
\hline$<30$ & $103 / 3038.3$ & 3.39 & 1 & 1 \\
\hline $30-39$ & $87 / 2628.4$ & 3.31 & $0.98(0.73-1.29)$ & $0.82(0.61-1.11)$ \\
\hline $40-49$ & $61 / 1644.2$ & 3.71 & $1.09(0.79-1.49)$ & $1.04(0.74-1.47)$ \\
\hline$>49$ & $26 / 637.3$ & 4.08 & $1.201(0.77-1.82)$ & $1.55(0.95-2.44)$ \\
\hline \multicolumn{5}{|l|}{ Residence area } \\
\hline $\begin{array}{l}\text { Living out of } \\
\text { Addis Ababa }\end{array}$ & 4/135.1 & 2.96 & $0.85(0.26-1.99)$ & $0.29(0.09-0.73)$ \\
\hline $\begin{array}{l}\text { Living in } \\
\text { Addis Ababa }\end{array}$ & 273/7800 & 3.50 & 1 & 1 \\
\hline \multicolumn{5}{|l|}{ Religion } \\
\hline Orthodox & $231 / 6243.2$ & 3.70 & $0.63(0.20-3.82)$ & $0.29(0.08-1.86)$ \\
\hline Muslim & 19/892 & 2.13 & $0.36(0.11-2.28)$ & $0.17(0.04-1.13)$ \\
\hline Protestant & $25 / 778.8$ & 3.21 & $0.55(0.16-3.40)$ & $0.32(0.09-2.12)$ \\
\hline Others* & $11 / 187.7$ & 5.86 & 1 & 1 \\
\hline \multicolumn{5}{|l|}{ Marital status } \\
\hline Married & $127 / 3547.5$ & 3.58 & $0.82(0.46-1.68)$ & $1.22(0.66-2.51)$ \\
\hline Single & 72/1889.8 & 3.81 & $0.88(0.48-1.81)$ & $1.18(0.63-2.48)$ \\
\hline Widowed & $33 / 1284$ & 2.57 & $0.59(0.30-1.27)$ & $0.81(0.40-1.76)$ \\
\hline Divorced & $35 / 997.2$ & 3.51 & $0.81(0.45-1.72)$ & $1.05(0.53-2.27)$ \\
\hline Separated & 10/229.9 & 4.35 & 1 & 1 \\
\hline \multicolumn{5}{|l|}{ Employment } \\
\hline Self employed & 87/3782.6 & 2.30 & $0.03(0.01-0.19)$ & $0.02(0.01-0.12)$ \\
\hline $\begin{array}{l}\text { Private } \\
\text { Employed }\end{array}$ & $58 / 1418.1$ & 4.09 & $0.06(0.02-0.35)$ & $0.03(0.01-0.16)$ \\
\hline $\begin{array}{l}\text { Government } \\
\text { employed }\end{array}$ & $62 / 1324.8$ & 4.68 & $0.07(0.02-0.40)$ & $0.03(0.01-0.19)$ \\
\hline Student & $3 / 66.5$ & 4.51 & $0.06(0.01-0.48)$ & $0.01(0.002-0.101)$ \\
\hline Non- employed & $65 / 1354.2$ & 4.80 & 1 & 1 \\
\hline \multicolumn{5}{|l|}{ Educational level } \\
\hline $\begin{array}{l}\text { None } \\
\text { educated }\end{array}$ & $42 / 1707.3$ & 2.46 & $0.65(0.35-1.33)$ & $1.25(0.62-2.70)$ \\
\hline $\begin{array}{l}\text { Primary } \\
\text { Completed }\end{array}$ & 106/3028.6 & 3.50 & $0.93(0.52-1.83)$ & $1.69(0.89-3.49)$ \\
\hline $\begin{array}{l}\text { Secondary } \\
\text { Completed }\end{array}$ & $118 / 2920.8$ & 4.04 & $1.07(0.60-2.10)$ & $1.76(0.97-3.55)$ \\
\hline $\begin{array}{l}\text { Tertiary } \\
\text { completed }\end{array}$ & $11 / 291$ & 3.78 & 1 & 1 \\
\hline
\end{tabular}

Table 5 Incidence rate, univariate and multivariate analysis among IPT completed, in-completed and non- exposed patients in public health facilities of Addis Ababa, during 2007-June 2012 (Continued)

\begin{tabular}{|c|c|c|c|c|}
\hline \multicolumn{3}{|c|}{$\begin{array}{l}\text { House Hold size/ } \\
\text { room no. }\end{array}$} & $0.99(0.89-1.09)$ & $0.98(0.88-1.07)$ \\
\hline \multicolumn{5}{|c|}{ Baseline WHO stage of HIV/AIDS } \\
\hline Stage $1 \& 2$ & $45 / 4545.5$ & 0.99 & $0.14(0.10-0.19)$ & $0.23(0.16-0.31)$ \\
\hline Stage $3 \& 4$ & 232/3381.9 & 6.86 & & 1 \\
\hline \multicolumn{5}{|l|}{$\begin{array}{l}\text { Baseline } C D_{4} \\
\text { cells/ } \mu \mathrm{l}\end{array}$} \\
\hline$\leq 200$ & $211 / 4169.9$ & 5.06 & $2.89(2.21-3.85)$ & $1.36(1.02-1.84)$ \\
\hline$>200$ & $66 / 3771.4$ & 1.75 & & \\
\hline \multicolumn{5}{|c|}{ Baseline weight in $\mathrm{Kg}$} \\
\hline$\leq 49$ & $113 / 2646.4$ & 4.27 & $1.88(1.12-3.43)$ & $1.63(0.93-3.05)$ \\
\hline $50-59$ & $108 / 3343.7$ & 3.23 & $1.42(0.85-2.59)$ & $1.19(0.69-2.22)$ \\
\hline $60-69$ & 42/1333.3 & 3.15 & $1.39(0.78-2.64)$ & $1.06(0.59-2.03)$ \\
\hline$>69$ & $14 / 616.7$ & 2.27 & 1 & 1 \\
\hline \multicolumn{5}{|l|}{ Baseline Ols } \\
\hline Yes & $194 / 6278.3$ & 3.09 & $0.62(0.48-0.80)$ & $1.24(0.95-1.63)$ \\
\hline No & $83 / 1660$ & 5.00 & 1 & 1 \\
\hline \multicolumn{5}{|l|}{ CPT adherence } \\
\hline Good & $271 / 7765$ & 3.49 & $0.99(0.48-2.51)$ & $0.92(0.44-2.37)$ \\
\hline $\begin{array}{l}\text { Fair, Poor \& } \\
\text { no CPT }\end{array}$ & $2 / 56.8$ & 3.52 & 1 & 1 \\
\hline
\end{tabular}

others include: catholic, johoba and non belivers

least a year were included as IPT exposed patients. All IPT discontinued patients regardless of their follow up time were also included. For comparison, equivalent number of non- IPT exposed patients who were on HIV care management for 1 or more years were sampled from randomly selected facilities which were not providing IPT till January 2010. All pediatric HIV positive patients regardless of whether they took/did not take IPT in the study period set, and all transferred in patients were excluded from this study. The patient charts from each facility were selected by random sampling method. A structured data abstraction format was used to collect information from medical records/chart of patients and the data was collected from July 1 to August 31, 2012. The data was entered and processed using SPSS version 16 statistical software. Descriptive statistics for patient characterization, Generalized Linear Model based on Poisson distribution to get incidence rate and incidence rate ratio, nonparametric test and Chi Square test were used for statistical analysis.

\section{Results}

A total of 2528 patients' charts were reviewed and four charts were with incomplete information and hence only 2524 charts were included in analysis. Of these, $1582(62.7 \%)$ were female and their mean age was 


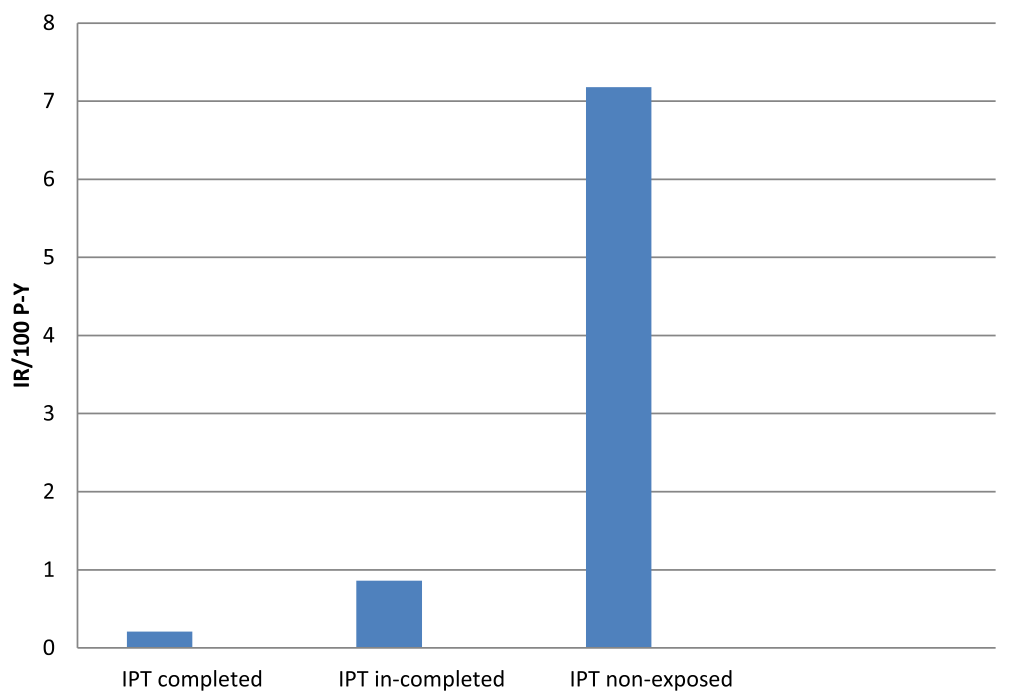

Fig. 1 Incidence rate among IPT completed, in-completed and non- exposed patientsin public health facilities of Addis Ababa, during 2007-June 2012

34.9 years. Majority were married and from Orthodox family. A significant proportion (44.9\%) was un-employed. There is significant difference in level of education, marital status and employment status (Table 1).

All of the patients were Pre-ART at the time of enrollment for chronic HIV care and the baseline clinical information of the patients is shown in Table 2. Majority of the patients were in stage 3 followed by stage 2, 972 (38.5\%) and 833 (33\%), respectively. There was significant clinical difference between the two groups.

As shown in Table 3, from all patients for whom their charts were reviewed, 2046 (81.1\%) had initiated HAART during their follow up; of whom 945 (46.2\%) of them were WHO stage 3.

Out of 1264 patients who were given IPT, completion rate was 975(77.1\%). Among IPT exposed patients; 942(74.5\%) were on HAART and of these $738(78.3 \%)$ completed IPT (Table 4).

Among 2524 HIV-infected patients who were followed for 4106 P-Y, 277 incident TB cases occurred, making the overall incidence of $6.7 / 100 \mathrm{P}-\mathrm{Y}$. Among IPT completed group, incidence rate was $0.21 / 100 \mathrm{PY}$, while in IPT nonexposed patients; it was 7.18/100P-Y. Incidence of TB was found to be associated with sex, employment status, baseline WHO stage of HIV/AIDS and $\mathrm{CD}_{4}$ count. Completion of IPT showed significant protective effect against occurrence of active TB when compared to IPT non-exposed patients aIRR $=0.037$ (CI 95\% 0.016-0.072) (Table 5, Fig. 1).

Similarly, as shown in Table 6 and Fig. 2, those patients who took IPT with HAART had TB incidence rate of $0.42 / 100 \mathrm{P}-\mathrm{Y}$ and among patients who took HAART alone, the incidence was 7.83/100P-Y. The concomitant use of IPT with HAART revealed significant protective effect on occurrence of active TB compared to HAART alone aIRR $=0.063(95 \%$ CI $0.035-0.104)$. Among IPT exposed patients, those who took IPT with HAART had lesser incidence than those who took IPT before initiating HAART $\{$ aIRR $=0.158(95 \%$ CI 0.039- 0.555) $\}$.

As shown in Table 7, there was significant CD4 and weight changes among IPT-HAART treated patients.

The median duration of follow- up was 40 months (inter-quartile range, $28-52$ months). From those who completed IPT, active TB has occurred between 6 and 28 months duration. Almost $50 \%$ of patients who completed IPT developed active TB at $19^{\text {th }}$ month; while in non-exposed patients TB occurred within a month time of enrollment (Table 8).

As shown in Table 9, IPT completers were significantly protected for 3 years $\{$ aIRR $=0.04 \quad(95 \%$ CI (0.02-1.74)\} compared to IPT in-completed and nonexposed patients.

Table 6 IR \& IRR among patients who took HAART with or without IPT in public health facilities of Addis Ababa, during 2007-June 2012

\begin{tabular}{lll}
\hline Therapy $(\mathrm{N}=1842)$ & $\mathrm{IR} / 100 \mathrm{P}-\mathrm{Y}$ & $\mathrm{alRR}(95 \% \mathrm{Cl})$ \\
\hline IPT with HAART & 0.42 & $0.063(0.035-0.104)$ \\
HAART only & 7.83 & 1 \\
IPT initiation time with HAART & & \\
Took IPT with HAART & 0.2 & $0.158(0.039-0.555)$ \\
Took IPT before initiating HAART & 0.75 & 1 \\
\hline
\end{tabular}




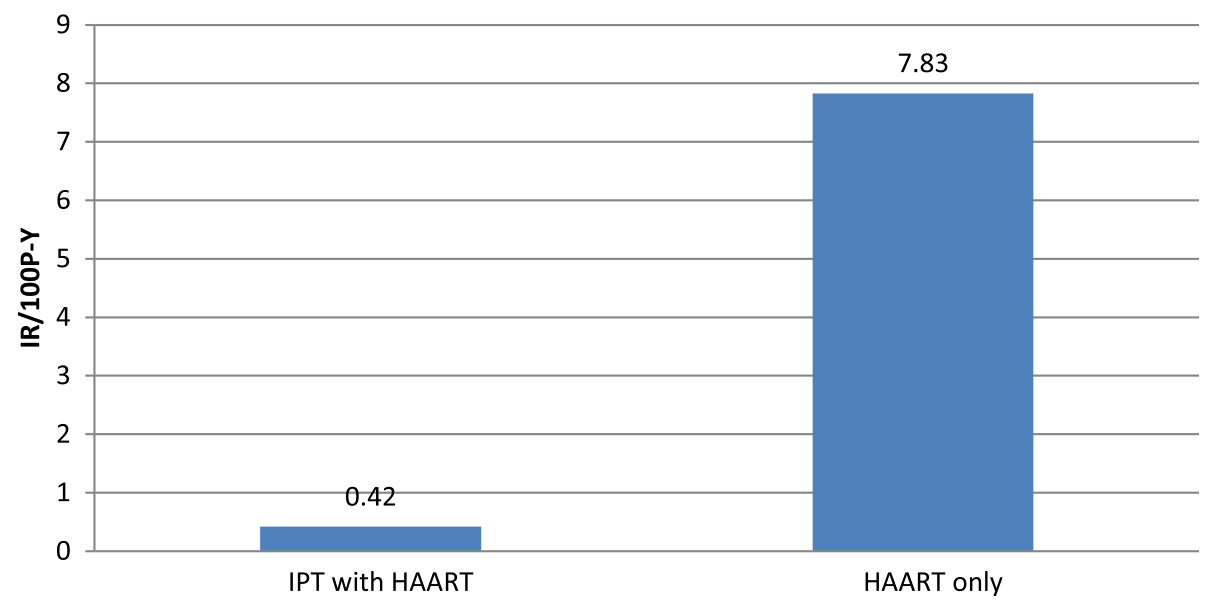

Fig. 2 IR among patients who took HAART with IPT in public health facilities of Addis Ababa, during 2007-June 2012

\section{Discussion}

This retrospective cohort study covering the time from 2007 to June 2012 attempted to assess effectiveness of IPT against active TB in HIV positive adults who were on HIV care in government health facilities of Addis Ababa. Accordingly, the IRs were 0.21/100P-Y, 0.86/100P-Y \& 7.18/100P-Y among IPT completed, in-completed \& nonexposed patients, respectively. The IR among IPT completed patients was lower when compared with the findings of studies done in different countries [11-13]. Moreover, completion of IPT in HIV infected adults significantly reduced TB incidence by $96.3 \%$ when compared to non-exposed patients (aIRR $=0.037,95 \% \mathrm{CI}$ $0.016-0.072$ ). The present study revealed abetter reduction in TB incidence after IPT in comparison with the results of earlier studies [7, 14-16]. Better patient adherence rate, difference in $\mathrm{TB}$ burden among the countries or better

Table 7 Statistical analysis of clinical data among patients who took HAART with IPT in public health facilities of Addis Ababa, during 2007-June 2012

\begin{tabular}{lllll}
\hline Variables & & $N$ & $\begin{array}{l}\text { Mean } \\
\text { Rank }\end{array}$ & P-value \\
\hline $\begin{array}{lllll}\text { Weight after completing } \\
\text { IPT - weight at enrollment }\end{array}$ & Negative Ranks & $160^{\text {a }}$ & 410.64 & \\
& Positive Ranks & $701^{\text {b }}$ & 435.65 & 0.000 \\
& Ties & $114^{c}$ & & \\
& Total & 975 & & \\
CD4 after completing & Negative Ranks & $253^{\text {d }}$ & 546.73 & \\
IPT - CD4 at enrollment & Positive Ranks & $702^{\mathrm{e}}$ & 453.23 & 0.000 \\
& Ties & $21^{\mathrm{f}}$ & & \\
& Total & 976 & & \\
& & & &
\end{tabular}

Weight when completing IPT < weight when starting IPT

${ }^{b}$ Weight when completing IPT > weight when starting IPT

${ }^{c}$ Weight when completing IPT = weight when starting IPT

${ }^{\mathrm{d}} \mathrm{CD} 4$ when completing IPT $<$ CD4 when starting IPT

${ }^{e} \mathrm{CD} 4$ when completing IPT > CD4 when starting IPT

${ }^{\mathrm{f}} \mathrm{CD} 4$ when completing IPT $=\mathrm{CD} 4$ when starting IPT socioeconomic and clinical status of patients might have contributed to such differences among studies conducted in different countries. Despite the fact that Ethiopia is among high TB burden country, IR among IPT completed patients was comparably lower than studies indicating further the effectiveness of IPT for HIV infected patients. Hence more widespread provision of IPT has the potential to further reduce TB incidence and hence improve quality of life among HIV infected adults in the country.

Among patients who completed IPT, though TB had occurred after 6 months, almost $50 \%$ of them developed TB at $19^{\text {th }}$ month; while in IPT non-exposed patients, half of patients developed active TB within a month time. The study proved that IPT has been significantly protecting early occurrence of $\mathrm{TB}$ during the first 6 months. This finding was comparable to the study done in Thailand where IR among IPT completers was 0 and among non-exposed patients 8.60/100 P-Y [17]. Moreover, the present study indicated that IPT had offered a significant protective effect until 3 years. The durability of protective effect of IPT documented in the present study concurs with the expected level indicated in Ethiopian guideline [10]. It is, however, better than reports from South East Asian and other Sub-Saharan African countries [13, 17, 18].

With regard to risk factors associated with TB occurrence, even though there is significant difference among the two groups in socio-demographic and baseline clinical characteristics, the multivariable analysis revealed significant influence of IPT completion, male sex, employment status, baseline WHO stage of HIV/AIDS (stage 3 \& 4) \& $\mathrm{CD}_{4}$ cell count (less than 200cells/ $\mu \mathrm{l}$ ).

Similarly, South African and Namibian studies indicated the influence of clinical factors on the incidence of Tb among HIV patients $[13,16]$.

Getahun et al. [19] reported that in countries with a high prevalence of $\mathrm{HIV}$, more women than men are 
Table 8 Month of occurrence of active TB among IPT completed, in-completed \& non-exposed patients in public health facilities of Addis Ababa, during 2007-June 2012

\begin{tabular}{|c|c|c|c|c|c|c|}
\hline Variables & $\begin{array}{l}\text { No of patients active } \\
\text { TB diagnosed }\end{array}$ & $\begin{array}{l}\text { Minimum month } \\
\text { TB occurred }\end{array}$ & $\begin{array}{l}\text { Maximum month } \\
\text { TB occurred }\end{array}$ & $\begin{array}{l}\text { Mean month } \\
\text { TB occurred }\end{array}$ & $\begin{array}{l}\text { Standard } \\
\text { Deviation }\end{array}$ & Median \\
\hline $\begin{array}{l}\text { Month TB occurred among IPT } \\
\text { completed patients }\end{array}$ & 7 & 6 & 28 & 16.7 & 8.4 & 19 \\
\hline $\begin{array}{l}\text { Month TB occurred among patients } \\
\text { who discontinued IPT }\end{array}$ & 8 & 0 & 35 & 9.6 & 14.8 & 0 \\
\hline $\begin{array}{l}\text { Month TB occurred among IPT } \\
\text { non-exposed }\end{array}$ & 262 & 0 & 65 & 8.1 & 13.3 & 1 \\
\hline
\end{tabular}

diagnosed with TB. But the current study revealed that more males who took IPT were at risk of developing active TB than females ( $\mathrm{aIRR}=1.596(95 \% \mathrm{CI}=1.203$ 2.117). This was in agreement with the report made by Golub et al. [20].

Concerning IPT initiation time with HAART, among IPT exposed patients; those patients who took IPT with HAART had $84.2 \%$ incidence reduction than those who took IPT prior to initiating HAART. This study also noted that there was significant $\mathrm{CD}_{4}$ cell count and weight changes after taking IPT-HAART combination therapy compared to cell count at enrollment, which might have contributed for preventing TB recurrence. This finding could serve as a base for further studies to reach an understanding on whether concomitant initiation of IPT with HAART or delayed initiation of IPT is better in terms of efficacy, toxicity or the development of immune reconstitution. In general the current finding encourages further implementation of the therapy in the country so as to decrease the burden of TB among HIV infected patients.

\section{Conclusions}

Completion of IPT significantly reduced TB incidence by 96.3\% and IPT had significantly protected occurrence of active TB for three years among HIV infected patients. Male sex, $\mathrm{CD}_{4}$ cell count less than 200cells/ $\mu \mathrm{l}$, WHO stage of HIV/AIDS 3 \& 4 and being non-employed were risk factors for $\mathrm{TB}$ incidence. Concomitant use of HAART with IPT significantly decreased TB incidence by $93.7 \%$ more than HAART alone. This result evidenced and supported the WHO recommendations that IPT protected the occurrence of active TB and proved the effectiveness of IPT in reducing TB incidence among

Table 9 TB incidence in month interval among IPT completed, in-completed \& non-exposed patients in public health facilities of Addis Ababa, during 2007-June 2012

\begin{tabular}{|c|c|c|c|c|}
\hline $\begin{array}{l}\text { Follow up } \\
\text { month }\end{array}$ & $\begin{array}{l}\text { IPT exposure/ } \\
\text { completion status }\end{array}$ & $\begin{array}{l}\text { IR/100 P-M } \\
(95 \% \mathrm{Cl})\end{array}$ & $\begin{array}{l}\text { Unadjusted IRR } \\
(95 \% \mathrm{CI})\end{array}$ & $\begin{array}{l}\text { Adjusted IRR } \\
(95 \% \mathrm{Cl})\end{array}$ \\
\hline \multirow[t]{3}{*}{$<6$} & Completed & 0 & 0 & 0 \\
\hline & In-complete & $142.8(17.64-268.07)$ & $1.82(0.65-3.97)$ & $2.125(0.712-5.103$ \\
\hline & Non-exposed & 78.59(66.9-90.3) & 1 & 1 \\
\hline \multirow[t]{3}{*}{$6-12$} & Completed & $12(1.58-25.58)$ & $0.30(0.06-0.79)$ & $0.03(0.013-1.95)$ \\
\hline & In-completed & $38.71(7.74-69.68)$ & $0.98(0.39-2.02)$ & $1.05(0.32-2.89)$ \\
\hline & Non-exposed & $39.43(34.05-44.82)$ & 1 & 1 \\
\hline \multirow[t]{3}{*}{$12-24$} & Completed & $6.74(1.35-12.14)$ & $0.29(0.11-0.59)$ & $0.03(0.01-0.74)$ \\
\hline & In-completed & $38.71(7.74-69.68)$ & $1.65(0.65-3.38)$ & $1.61(0.51-4.29)$ \\
\hline & Non-exposed & $23.51(20.48-26.55)$ & 1 & 1 \\
\hline \multirow[t]{3}{*}{$24-36$} & Completed & $5.98(1.55-10.42)$ & $0.34(0.14-0.66)$ & $0.04(0.02-1.74)$ \\
\hline & In-completed & 9.94(3.05-16.82) & $0.56(0.25-1.05)$ & $1.09(0.49-2.54)$ \\
\hline & Non-exposed & $17.87(15.63-20.11)$ & 1 & 1 \\
\hline \multirow[t]{3}{*}{$37-48$} & Completed & $5.98(1.55-10.42)$ & $0.44(0.186-0.854)$ & $0.74(0.301-1.56)$ \\
\hline & In-completed & $9.94(3.05-16.82)$ & $0.73(0.33-1.37)$ & $0.72(0.314-1.44)$ \\
\hline & Non-exposed & 13.72(12.04-19.56 & 1 & 1 \\
\hline \multirow[t]{3}{*}{$>48$} & Completed & $5.98(1.55-10.42)$ & $0.50(0.22-0.99)$ & $0.88(0.36-1.84)$ \\
\hline & In-completed & $9.94(3.05-16.82)$ & $0.84(0.38-1.58)$ & $0.89(0.39-1.76)$ \\
\hline & Non-exposed & 11.88(10.44-13.32) & 1 & 1 \\
\hline
\end{tabular}


HIV infected patients in Ethiopia. Therefore, it should be implemented widely for HIV-infected patients in all parts of the country so as to improve their quality of life by reducing the TB burden and prevent further transmission of TB in the community.

\section{Abbreviations}

IPT: Isoniazid preventive therapy; alRR: Adjusted incidence rate ratio: HAART: Highly active antiretroviral therapy; IR: Incidence ratio; PMTCT: Prevention of mothers to child transmission of HIV; TB: Tuberculosis; WHO: World Health Organization; UNAIDS: United Nation programs on HIV/AIDS

\section{Acknowledgments}

Special thanks go to Addis Ababa University, Graduate Study Program and KNCV TB Care I of Ethiopia for financially sponsoring this research.

\section{Funding}

Graduate Program of Addis Ababa University and KNCV TB Care I-Ethiopia.

\section{Availability of data and materials}

Due to confidentiality issues, the raw data will not be shared.

\section{Authors' contributions}

MS designed the study, supervised the data collection, did the analysis and drafted the manuscript; TGF involved in the design and conduct of the study including approval of the manuscript; GG and DA substantially contributed in data analysis and all authors read and approved the final manuscript.

\section{Competing interests}

All authors declared that there is no competing interest.

\section{Consent for publication}

Not applicable.

\section{Ethics approval and consent to participate}

Ethical approval was obtained from the Research and Ethics Review Committees of the School of Pharmacy, Addis Ababa University, ALERT/AHRI and Addis Ababa Regional Health Bureau. Since the data was taken as part of a routine service, participants' consent was not a requirement. Instead, Institutional consent was secured from each participating health facility to use the data.

\section{Author details}

${ }^{1}$ Addis Ababa Health Bureau, Addis Ababa, Ethiopia. ${ }^{2}$ Social and Administrative Pharmacy Working Group, Department of Pharmaceutics and Social Pharmacy, College of Health Sciences, Addis Ababa University, P.O. Box 1176, Addis Ababa, Ethiopia. ${ }^{3}$ Aklilu Lemma Institute of Pathobiology, Addis Ababa University, Addis Ababa, Ethiopia. ${ }^{4}$ KNCV TB Care I-Ethiopia, Addis Ababa, Ethiopia.

Received: 19 April 2016 Accepted: 10 December 2016

Published online: 03 January 2017

\section{References}

1. Friedland G, Churchyard GJ, Nardell E. Tuberculosis and HIV coinfection: current state of knowledge and research priorities. JID. 2007;196 Suppl 1:S1.

2. WHO. WHO Three I's Meeting Intensified Case Finding (ICF). Isoniazid Preventive Therapy (IPT) and TB Infection Control (IC) for people living with HIV. Geneva: Report of a Joint World Health Organization HIV/aids and TB Department Meeting; 2008. http://www.who.int/hiv/pub/tb/3is_mreport/ en/. (Accessed 20 Oct 2015).

3. CDC. TB and HIV coinfection. http://www.cdc.gov/hiv/pdf/g-l/cdc-hivhivandtb.pdf. (Accessed 4 Oct 2015).

4. Lawn SD, Harries AD, Anglaret $X$, et al. Early mortality among adults accessing antiretroviral treatment programmes in sub-Saharan Africa. AIDS 2008;22:1897-908.

5. WHO. TB/HIV 2012/2013 factsheet. http://whalibdoc.who.int/publications/ 2011/9789241501569_eng.pdf. (Accessed 20 Oct 2015).
6. FMOH. Health Sector Development Program IV, 2010/11 - 2014/15. Federal Democratic Republic of Ethiopia, Ministry of Health. Version 19. Addis Ababa, Ethiopia

7. WHO. Guidelines for intensified tuberculosis case finding and isoniazid preventive therapy for people living with HIV in resource constrained settings. Geneva, Switzerland; 2011. http://www.who.int/hiv/pub/tb/ 9789241500708/en/. (Accessed 30 Oct 2015).

8. World Health Organization Global Tuberculosis Programme/Joint United Nations Programme on HIV/AIDS. Policy statement on preventive therapy against tuberculosis in people living with HIV. Geneva: The Organization; 1998. WHO/TB/98.255. http://www.who.int/docstore/gtb/publications/TB_ HIV_polstmnt/index.html. (Accessed on 30 Oct 2015).

9. WHO. Programmatic update: Antiretroviral Treatment as Prevention (TASP of HIV and TB. http://www.who.int/hiv/pub/mtct/programmatic_update_ tasp/en/. (Accessed 25 Oct 2015).

10. FMOH: Implementation Guideline for TB/HIV Collaborative Activities in Ethiopia. Federal Ministry of Health: Addis Ababa, Ethiopia; 2008/09.

11. Belew D. Process evaluation of isoniazid prophylaxis program for HIV positive patients in the ENARP site. Master's thesis. Addis Ababa: Department of Community Health, Addis Ababa University; 2004.

12. Vieira de Souza CT, Hökerberg YHM, Pacheco SJB, et al. Effectiveness and safety of isoniazid chemoprophylaxis for HIV-1 infected patients from Rio de Janeiro. Mem Inst Oswaldo Cruz. 2009;104(3):462-7.

13. Teferi T, Iyaloo J, Kalibbala M, Makai R, Hango JN, Nkongolo OT, et al. Effect of primary isoniazid preventive therapy on tuberculosis incidence rate among HIV-infected adults enrolled in HIV care in northern Namibia: a retrospective cohort study. In: AIDS 2012 - XIX International AIDS Conference, 2012: Abstract WEPE066. $22-27$ July 2012. Washington, D.C. http://pag.aids2012.org/Abstracts.aspx?AID=7130. (Accessed 25 Oct 2015).

14. Woldehanna S, Volmink J. Treatment of latent tuberculosis infection in HIV infected persons (Cochrane Review). The Cochrane Library, Issue 3. Chichester (UK): Wiley; 2004.

15. Fennera $L$, Forstera $M$, Boulleb $A$, et al. Tuberculosis in HIV programmes in lower-income countries: practices and risk factors. Int J Tuberc Lung Dis. 2011;15(5):620-7.

16. Grant $A D$, Charalambous $S$, Fielding $K L$, et al. Effect of routine isoniazid preventive therapy on tuberculosis incidence among HIV-infected men in South Africa: a novel randomized incremental recruitment study. JAMA. 2005;293(22):2719-25.

17. Khawcharoenporn T, Apisarnthanarak A, Manosuthi W, et al. Isoniazid preventive therapy and 4-year incidence of pulmonary tuberculosis among HIV infected Thai patients. Int J Tuberc Lung Dis. 2012;16(3):336-41. doi:10. $5588 /$ ijtld.11.0402

18. World Health Organization (WHO). Report of a "lessons learnt" workshop on the six ProTEST pilot projects in Malawi, South Africa, and Zambia [WHO/ HTM/TB/2004.336]. Geneva: WHO; 2004.

19. Getahun H, Gunneberg C, Granich R, et al. HIV infection associated tuberculosis: the epidemiology and the response. Clinical Infectious Diseases. 2010;50 suppl 3:S201-7. doi:10.1086/651492.

20. Golub EJ, Pronyk P, Mohapi L, et al. Isoniazid preventive therapy, HAART and tuberculosis Risk in HIV-infected adults in South Africa: a prospective cohort. AIDS. 2009;23(5):631-6.

\section{Submit your next manuscript to BioMed Central} and we will help you at every step:

- We accept pre-submission inquiries

- Our selector tool helps you to find the most relevant journal

- We provide round the clock customer support

- Convenient online submission

- Thorough peer review

- Inclusion in PubMed and all major indexing services

- Maximum visibility for your research

Submit your manuscript at www.biomedcentral.com/submit
) Biomed Central 